\title{
調音機能と補緅物との関係
}

\section{Relation between Articulatory Function and Prosthesis}

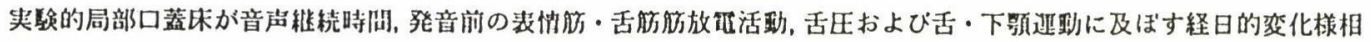

Longitudinal Changing Aspects in the Duration of Speech Sound Muscular Discharge of Facial Muscles and Tongue Muscle.

Tongue Pressure, Tongue Movement and Mandibular Movement Before Pronunciation Caused by the Experimental Partial Palatal Plate 竹内英明，森谷良彦
\end{abstract}

Hideaki Takeuchi, Yoshihiko Moriya

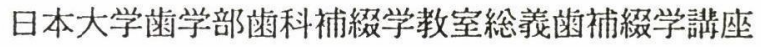

Department of Complete Denture Prosthodontics, Nihon University School of Dentistry

\section{I . 緒言}

発音器官における言語音生成過程は，呼吸，発 声, 共鳴, 調音および制御・統合の 5 段階に分け られる”。特に調音の段階において, 床義菌装着 などによるロ腔内環境の変化による 発音およ びロ䏕諸器官の受ける影響について,これまでに 聴覚的な研究2,3), ソナグラムによる研究3.4), 音響 学的な研究 ${ }^{5}$ 7), 舌の接触圧による研究8,99, 筋電図 学的研究 ${ }^{(0 \sim 13)}, \mathrm{X}$ 線学的な研究(1) および付属管腔 内気流などの気圧による研究が行われてきた。

浜中 ${ }^{15)}$ 扰よび萩原 ${ }^{(6)}$ は, 総義歯装着者を想定 した健常有柬顎者に対し, 筋電図学的, 運動学的 および力学的な検索を行い, 各調音器官の自己補 正様相を報告している.

そこで著者らは, 上䫑局部床義菌の大速結子に ついて注目し, 大連結子の走行位置による差異が, 各調音器官の機能に及ぼす影響について検索す ることとし. 先ず, 中パラタルバーを有する実験 的局部口蓋床を健常有蒾頇者に装着させ, 各調音 器官の自己補正様相について, 筋電図学的には表 情筋および舌筋筋放電活動, 力学的には舌圧, 運 動学的には舌および下顎運動について, 経日的検 索を行った。

\section{II. 材料および方法}

\section{1 .被検者}

被検者は顎口腔系に巽常を認めず個性正常咬 合を有する健常有蒾顎者であり, 自覚的および他 覚的に発音障害, 聴覚障害书よび舌買常を認めな
い東京都出身の $21 \sim 25$ 歳男性 3 名とした.

\section{2. 被檢音}

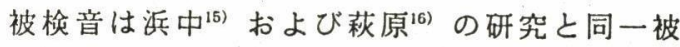
検音であり，有床義菌装着により発音障害を受け

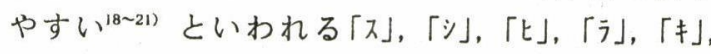
「子」および「サ」の 7 単音節とした。

\section{3. 実験的局部口蓋床}

中パラタルバーを有する実験的局部口蓋床（以 下，中パラ床と略す）の調製に際して，その形態 は両側第二小臼歯, 第一および第二大臼歯欠損の 両侧遊離端局部床義菌を想定した。

中パラ㦿は, 義蒾床および中パラタルバーから 構成され, 義菌床は煩舌的な大きさは口蓋菌頸部 侧の口蓋幅径の $1 / 6$ の範国であり，近遠心的には 両侧第一および第二小臼蒾のコンタクトポイン 卜を結ぶ線から上顎結節を覆うまでの範囲とし， その厚さを $2.0 \mathrm{~mm}$ とした。

中パラタルバーの形態は幅径 $3.7 \mathrm{~mm}$, 厚さ $1.3 \mathrm{~mm}$ のかまぼこ状であり，その走行は両側第二小臼歯 舌侧咬頭頂を結ぶ線上に位置し, 義㐘床の前縁へ

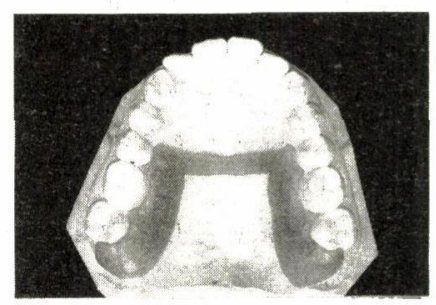

図 1 実験的局部口蓋床 
移行させた。なお，中パラタルバーとロ蓋粘膜 とのリリーフは，約 $0.5 \mathrm{~mm}$ とした。

この中パラ床は、アルジネート印象採得による 上颚石亶模型を用い，各被梌者にそれぞれ 2 林ず つ加熱重合型義茵床用レジンにて調製した。

\section{4.测定装置および方法}

测定方法. 被検音および分析方法は，浜中 ${ }^{(5)} お$ よび萩原间の方法に準じた。

1) 音声

音声の测定には, 被検者とマイクロフォンと約 $30 \mathrm{~cm}$ の距離に保つように楽に座らせ，音声の大き さおよび発音方法は，被検者に日常会話と同様に 行うように指示し、トリガーに追従させて各被検 音を 5 回発音させた.

2）発音前の表情筋筋放電活動

表悄筇笳放電活動として，口鍮筋（以下，00S と略す）および下居下制筇（以下，DLIと略す）を 被験筋とした。

両被検能の導出部位は，O0Sでは顔面正中線と 口角線との中央で上口唇赤管縁から上方 $5 \mathrm{~mm}$ とし， DLIは顔面正中線と口角線との中央でオトガイ唇 帮とオトガイ下点との中央とした（因2).

3) 発音前の舌圧

圧カセンサ共和電業社製PS-2KAの設置部位は浜 中占) の方法に準し， $P_{1} \sim P_{4}$ とした（図 3).なお， $\mathrm{P}_{3}$ は実験的局部口蓋床上に設置した。

4) 発音前の舌筋筋放電活動

舌筋筋放電活動の導出は，有効直径 $4.0 \mathrm{~mm}$ ，厚 さ $1.3 \mathrm{~mm}$ の銀製表面血電極を用い，その導出部位 は舌を最大笑出させた状揸で舌尖から $20 \mathrm{~mm}$, 舌正

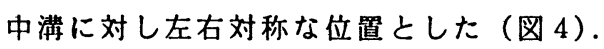

5）発音前の舌運動

舌運動の測定は磁気を応用した非接触型下䪽 運動記録装置であるシロナソグラフ（シーメン ス社，D3175，以下， SGG之略す）を用いた。

また、マグネットは調音機能への障害を考虑し， 改良型マグネット ${ }^{16)}(\phi 2 \times 10 \mathrm{~mm}, 0.23 \mathrm{~g})$ を用い た。

マグネットの設定は，舌を前へ最大突出させた 舌尖から15 mmで, 舌正中满とマグネットの長軸と が直行する位置とした。

SGGは，舌安静位を基準として测定を行った。

6）発音前の下影運動

下顥運動の测定にも改良型マグネットを応用し
たSGGを用いた。

マグネットの設定は，下额前菌部の正中線上と し、下颔安静位を基準位として测定を行った。

\section{5. 分析方法}

実験的局部口蓋床装着による調音機能への影 響を検索する目的で，1.音声継続時間，発音前の 2.表情筇筇放電活動，3.舌圧，4.舌筋解放電活動， 5. 舌運動および6.下影運動の 6 項目について行 った.

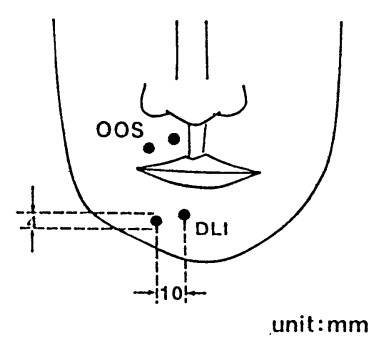

図 2 表情解放放電活動導出部位 (浜中ら ${ }^{16)}$ より引用)

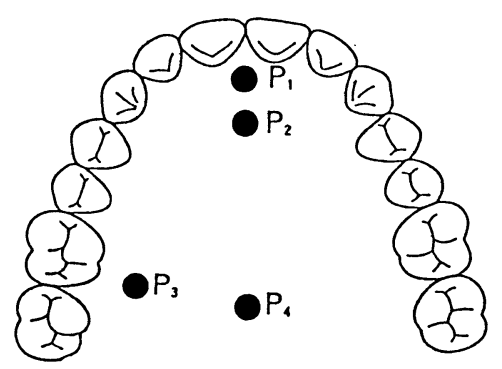

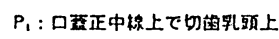

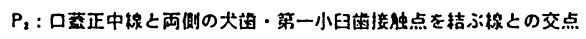

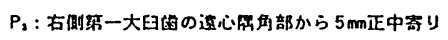

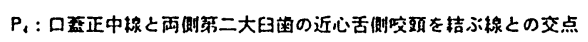

図 3 圧力センサ設置部位 
1) 音声継続時間

音声継続時間では, 先行子音開始時を $\mathrm{S}_{1}$, 後続 母音開始時を $S_{2}$, 後続母音終了時を $S_{3}$ とし, $S_{1}$ と $\mathrm{S}_{2}$ および $\mathrm{S}_{2}$ と $\mathrm{S}_{3}$ の時間差をそれぞれ先行子音継 続時間および後続母音継続時間を求めた（図 5 ).

2）発音前の表情筇施放霔活動

表情筋筋放霔活動では，表情筋筇放電活動開始 時を $\mathrm{FO}_{1}$ おび $\mathrm{FD}_{1}$ とし，F0、および $\mathrm{FD}_{1}$ から $\mathrm{S}_{1}$ までの 能放電持続時間および筋放電持続時間における 筋活動量を求めた（図 5).

3) 発音前の舌圧

舌圧では，舌接触開始時を $T_{1}$ とし， $S_{1}$ までの 舌接触持続時間および舌接触持続洔間における 積分值（以下, 舌王量とする）を求めた（図 5 ). なお, 今回ではセンサ設置 $\mathrm{P}_{3}$ について検索した。

4) 発音前の舌筋筋放電活動

舌筋筋放電活動では，舌筋筋放電活動閶始時を $E_{1}$ とし， $E_{1}$ から $S_{1}$ までの施放電持続時間および 筋放電持続時間における筋活動量を求めた（図 5).

5）発音前の舌運動

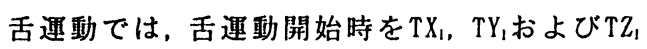
とし， $S_{1}$ までの舌運動時間およびこの舌運動時 間における積分値（以下，舌連動量とする）を求 めた (図6).

6）発音前の下頻遇動

下䪽運動では，下䪽運動開始時をMX, MY およ びMZ とし， $S_{1}$ までの下頻運動時間およびこの下 頻運動時間における積分值（以下，下頻運動量と する）を求めた（図6）.

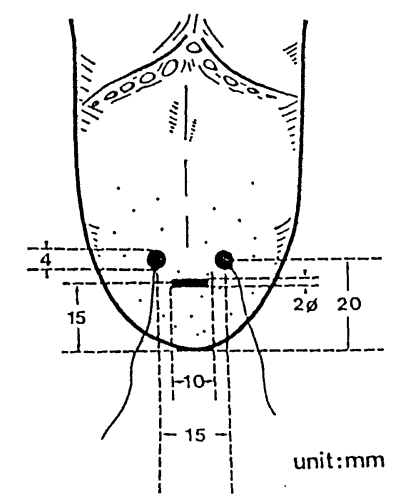

図 4 マグネットおよび表面電極の設固部位

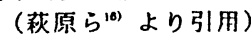

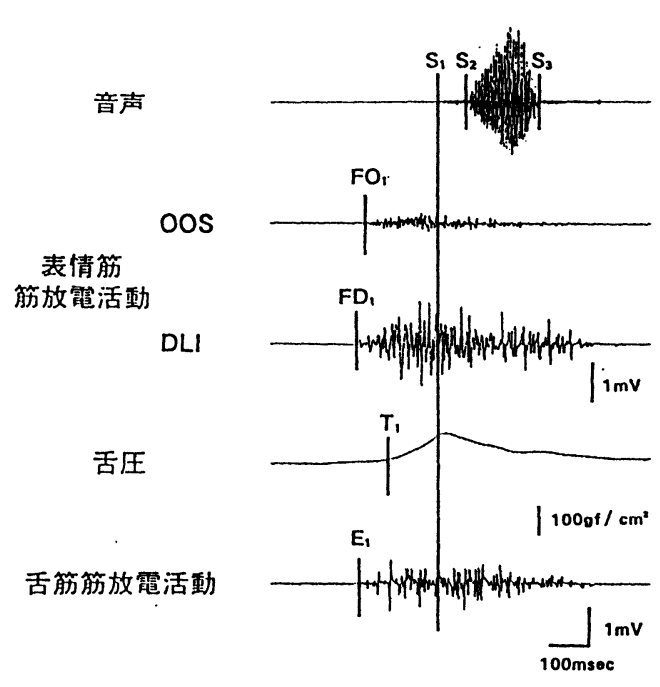

図 5 音声，表情筇，舌圧，舌筋における分析方法

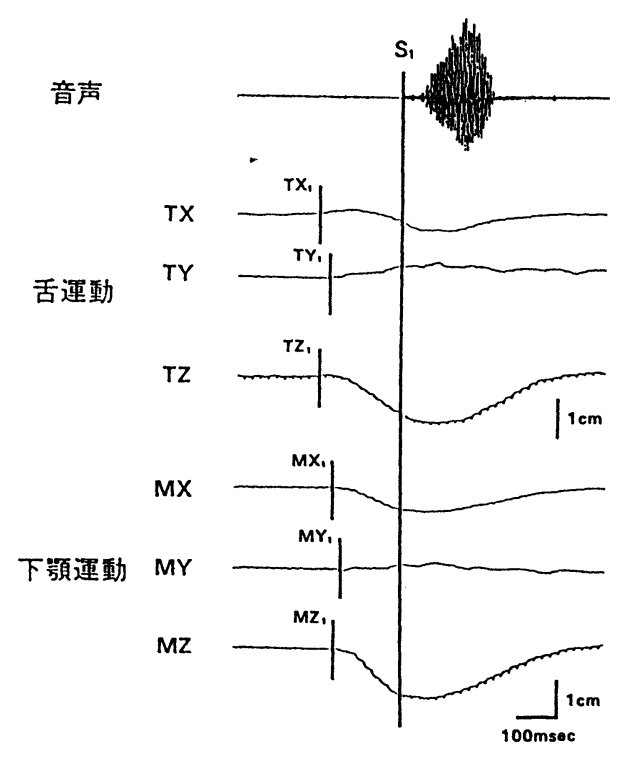

図6 舌運動および下頻運動における分析方法

なお，测定期日は，中パラ床装着前（以下，Before とする）を基準とし，中パラ床装着直後（以下， Afterとする)，3日後，7日後および14日後とし た. 
得られた测定值を被榆音および各测定期日ご との平均值および標準偏差を求め, 装着前に対す る装着直後，3，7および14日後のそれぞれと $\mathrm{t}$ 一検定

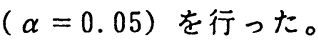

\section{III.結果}

\section{1）音声継続時間}

先行子音継続時間および後続母音継続時間の 成績は表 1 , 各被榆音の装着前後の $\mathrm{t}$ 一検定結果 は表 2 に示した。

先行子音継繶時間では，Beforeに比して，全被 検音はAfterで有意に延長し、「州は 3 日後。「七」, 「う」および「キ」は 7 日後, 他の被検音は14日後に同 程度を示した。

後続母音継続時間では，全被検音はAfterから 同程度を示した。

\section{2）発音前の表情筋筋放電活動}

発音前の表情笳（00S，DLI）の館放電持続時間 および笳活動量の成績は表 3 および 4 ，各被検音 の装着前後の $\mathrm{t}$ 一榆定結果は表 5 および 6 に示し た。

筋放持続時間では，Beforeに比して，全被検音 はAfterで有意に延長し、「ス」および「七」は 3 日後， 「サ」は 7 日後，その他の被検音は 14 日後に同程度 を示した。

筋活動量では両被検筋ともに，全被検音は，After で有意に增加し，その他の被検音は14日後に同程 度を示した０0Sの筋活動量では，DLIに比して， 被検音の一部が早く同程度を示す傾向であった。

3）発音前の舌圧

$\mathrm{P}_{3}$ ににおける発音前の舌接触持続時間および舌 圧量の成績は表 7 および 8 , 各被検音の装着前後 の $\mathrm{t}$ 一検定結果は表 9 および10に示した。

舌接触持続時間では，Beforeに比して，「棉お よび「キ」はAfterから同程度であった，他の被検音 はAfterで有意な延長を認め。「ス」および「子」は 3 日後,「シ」は 7 日後に同程度を示した。

舌圧量では，「キ」はAfterから同程度であった。 他の被検音はAfterで有意な延長を認め,「シ」と 「七」は 3 日後、「子」は14日後に同程度であったが， 「ス」は14 日後も有意に延長した。
表 1 音声継続時間

\begin{tabular}{|c|c|c|c|c|c|}
\hline Sound 器音 & Before & After & 3days & 7 days & 14days \\
\hline 久喑 & $\begin{array}{l}112.1 \\
188.5\end{array}\left(\begin{array}{c}9.0 \\
91.9\end{array}\right)$ & $\left.\begin{array}{l}137.1(13.33 \\
194.0(11.1)\end{array}\right)$ & $\begin{array}{l}122.0 \\
1922.1\end{array}(15.2)$ & $\begin{array}{l}121.1 \\
185.6\end{array}(11.96)$ & $\begin{array}{l}110.1 \\
184.5\end{array}(17.6)$ \\
\hline シ䅧 & $\left.\begin{array}{l}113.9(10.0) \\
196.9(11.0)\end{array}\right)$ & $\begin{array}{l}136.9(19.66) \\
183.5(13.3)\end{array}$ & $\begin{array}{l}129.6 \\
1992.5(15.8)\end{array}$ & $\begin{array}{l}129.1(11.0) \\
189.5\end{array}$ & $\begin{array}{l}112.5(10.9) \\
194.1(17.6)\end{array}$ \\
\hline 七委意 & $\begin{array}{r}72.7(14.2) \\
189.1(20.8)\end{array}$ & $\begin{array}{r}95.7(21.88) \\
195.2(10.66)\end{array}$ & $\begin{array}{r}86.7(17.1) \\
201.7(14.2)\end{array}$ & $\begin{array}{r}78.8(16.2) \\
192.7(19.1)\end{array}$ & $\begin{array}{r}83.7((19.3) \\
194.9(16.9)\end{array}$ \\
\hline う喑 & $\begin{array}{c}72.0(9.8 .85 \\
183.1(12.5)\end{array}$ & $\begin{array}{l}86.5(14.2 .2 \\
187.1121 .7\end{array}$ & $\begin{array}{l}81.64(16.5 .5) \\
188.9(15.6)\end{array}$ & $\begin{array}{c}73.3 .310 .44) \\
185.9(13.1)\end{array}$ & $\begin{array}{r}78.1(8.0) \\
178.5(15.2)\end{array}$ \\
\hline キ喑 & $\begin{array}{r}66.7(79.6) \\
189.3(10.5)\end{array}$ & $\begin{array}{l}84.9(11.77) \\
183.2(14.5)\end{array}$ & $\begin{array}{r}84.9(11.7) \\
196.5(12.6)\end{array}$ & $\begin{array}{r}71.5(8.38 \\
184.7(15.4)\end{array}$ & $\begin{array}{c}70.0(9.5) \\
184.7(22.7)\end{array}$ \\
\hline 千 喑 & $\begin{array}{r}66.7(11.8) \\
193.2(16.8)\end{array}$ & $\begin{array}{r}87.5(16.0)- \\
198.9(12.9)-\end{array}$ & $\begin{array}{r}84.1(10.8) \\
191.1(16.1)\end{array}$ & $\begin{array}{r}95.5(25.2) \\
189.5(21.2)\end{array}$ & $\begin{array}{l}69.1\left({ }_{(8.4)}^{8.4}\right) \\
190.4(13.5)\end{array}$ \\
\hline ＼cjkstart敀 & $\begin{array}{c}79.7(12.3 .3) \\
186.3(16.6)\end{array}$ & $\begin{array}{r}91.7(177.63) \\
193.2(20.3)\end{array}$ & $\begin{array}{r}85.7(16.7) \\
197.3(15.7)\end{array}$ & $\begin{array}{r}83.6(13.0) \\
181.718 .0)\end{array}$ & $\begin{array}{r}82.0(10.007 \\
188.911 .7\end{array}$ \\
\hline & & & & & ( $1: S D$ \\
\hline
\end{tabular}

表2 音声継結時間の $\mathrm{t}$ - 検定結果

\begin{tabular}{|c|c|c|c|c|c|c|c|c|}
\hline \multirow{2}{*}{$\begin{array}{l}\text { Sound } \\
\text { Soun } \\
\end{array}$} & \multicolumn{4}{|c|}{ 先行子音 } & \multicolumn{4}{|c|}{ 後䗋时普 } \\
\hline & After & 3days & 7days & 14days & After & 3days & 7days & 14days \\
\hline z & + & + & + & - & - & - & - & - \\
\hline$=$ & + & + & + & - & - & - & - & - \\
\hline E & + & + & - & - & - & - & - & - \\
\hline $\Rightarrow$ & + & + & - & - & - & - & - & - \\
\hline$\neq$ & + & + & - & - & - & - & - & - \\
\hline チ & + & + & + & - & - & - & - & - \\
\hline サ & + & - & - & - & - & - & - & - \\
\hline
\end{tabular}

表 3 発音前における表悄肪肪放電持続時間

\begin{tabular}{|c|c|c|c|c|c|}
\hline Sound 被楼觔 & Before & After & 3days & 7days & 14days \\
\hline & $\begin{array}{l}210.9(15.2) \\
214.1(19.5)\end{array}$ & $\begin{array}{l}264.9(24.6) \\
280.9(26.7)\end{array}$ & $\begin{array}{l}223.9(70.8) \\
241.5(64.0)\end{array}$ & $\begin{array}{l}222.7(33.1) \\
232.3(35.6)\end{array}$ & $\begin{array}{l}220.8(32.0) \\
224.8(23.5)\end{array}$ \\
\hline シ $\begin{array}{l}0 \\
\text { OLL } \\
\text { DLI }\end{array}$ & $\begin{array}{l}209.3(21.1) \\
221.3(22.1)\end{array}$ & $\begin{array}{l}275.6(32.5) \\
295.2(39.8)\end{array}$ & $\begin{array}{l}243.5(27.3) \\
253.7(33.6)\end{array}$ & $\begin{array}{l}246.4(22.5) \\
253.6(23.1)\end{array}$ & $\begin{array}{l}207.1(29.6) \\
226.0(25.3)\end{array}$ \\
\hline 匕 & $\begin{array}{l}202.4(19.2) \\
215.2(17.6)\end{array}$ & $\begin{array}{l}254.1(55.5) \\
260.5(54.4)\end{array}$ & $\begin{array}{r}214.5(36.2) \\
235.7(36.3)\end{array}$ & $\begin{array}{l}218.0(35.8) \\
226.7(38.5)\end{array}$ & $\begin{array}{l}194.0\left(\begin{array}{l}43.4 \\
206.1 \\
(26.3)\end{array}\right)\end{array}$ \\
\hline $\begin{array}{lll} & 0 & 0 \\
D & L & 1\end{array}$ & $\begin{array}{l}1777.2(19.66 \\
190.026 .2\end{array}$ & $\begin{array}{l}223.1(44.3) \\
229.1\end{array}$ & $\begin{array}{l}212.9(323.3) \\
226.4(30.3)\end{array}$ & $\begin{array}{l}206.9(39.4) \\
216.7(41.5)\end{array}$ & $\begin{array}{l}177.7(752.7) \\
203.6(34.3)\end{array}$ \\
\hline$\neq \begin{array}{l}00 S \\
D L I\end{array}$ & $\begin{array}{l}2025.5(25.1 .1 \\
2177\end{array}$ & $\begin{array}{l}301.6(38.7) \\
319.741 .9\end{array}$ & $\begin{array}{l}245.9(46.8) \\
558.1\end{array}$ & $\begin{array}{l}245.9(27.7) \\
258.1\end{array}$ & $\begin{array}{l}193.7(39.6) \\
221.3(31.1)\end{array}$ \\
\hline & $\begin{array}{l}2239.9(319.9 .9) \\
23336(29.7)\end{array}$ & $\begin{array}{l}294.5(38.5 \\
314.736 .5\end{array}$ & $\begin{array}{l}264.3(292.2) \\
2099.9(42.9)\end{array}$ & $\begin{array}{l}260.5(30.1) \\
287.1\end{array}$ & $\begin{array}{l}217.77(25.1) \\
238.3(23)\end{array}$ \\
\hline 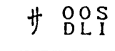 & $\begin{array}{l}211.1(26.3) \\
221.2(20.7)\end{array}$ & $\begin{array}{l}2355(524.2) \\
252.5(28.4)\end{array}$ & $\begin{array}{l}242.8(22.8 \\
266.5(25.8)\end{array}$ & $\begin{array}{l}215.2(51 \cdot 1) \\
232.8(31 \cdot 2)\end{array}$ & $\begin{array}{l}202.7(17.7) \\
228.9(27.7)\end{array}$ \\
\hline & & & & & \\
\hline
\end{tabular}


表 4 発音前における表情筋筋活動量

\begin{tabular}{|c|c|c|c|c|c|}
\hline Sound 被赤知 & Before & After & 3days & Tdays & 14days \\
\hline$\lambda \underset{0}{00 S}$ & $\left.\begin{array}{ccc}10.2 & 2.1 \\
13.1 & 2.8\end{array}\right)$ & $\begin{array}{l}13.8 \\
15.2\end{array}\left(\begin{array}{l}3.0 \\
2.5\end{array}\right)$ & $\begin{array}{l}12.4\left(\begin{array}{l}4.4 \\
15.5 \\
2.4\end{array}\right)\end{array}$ & 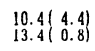 & \begin{tabular}{r|r|r}
9.6 & 3.4 \\
13.3 & 1.6
\end{tabular} \\
\hline シ $\begin{array}{l}O O S \\
\text { DLI }\end{array}$ & $\left.\begin{array}{rl}8.0 & 0.7 \\
25.2 & 9.2\end{array}\right)$ & $\left.\begin{array}{c}11.6 \\
33.8(10.6)\end{array}\right)$ & $\left.\begin{array}{rr|r}3.0 & 1.5 \\
34.6 & 7.3\end{array}\right)$ & $\begin{array}{c}11.0 \\
23.2\end{array}\left(\begin{array}{l}3.6 \\
7.5\end{array}\right)$ & $\begin{array}{c}8.2(0.8) \\
30.818 .8\}\end{array}$ \\
\hline t $\begin{array}{l}O O O S \\
D L I\end{array}$ & 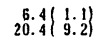 & $\begin{array}{c}9.2 \\
34.0\end{array}\left(\begin{array}{l}1.4 \\
9.7\end{array}\right)$ & $\begin{array}{r}7.0 \\
38.0\end{array}\left(\begin{array}{l}1.2 \\
38\end{array}\right)$ & $\begin{array}{r}7.2 \\
15.8\end{array}\left(\begin{array}{l}1 \\
5.1\end{array}\right)$ & $\begin{array}{r}5.4(1.1) \\
21.4(7.9)\end{array}$ \\
\hline ラ $\begin{array}{l}00 S \\
0 L L\end{array}$ & $\begin{array}{r}5.2\left(\begin{array}{l}0.8 \\
18.8 \\
8.3\end{array}\right)\end{array}$ & $\begin{array}{rr}9.0 & \left(\begin{array}{c}6.5 \\
27.6 \\
6.7\end{array}\right)\end{array}$ & $\begin{array}{r}5.2\left(\begin{array}{l}1.3) \\
24.4 \\
3.8\end{array}\right)\end{array}$ & \begin{tabular}{r|r|r|r}
5.4 & 1.0 \\
16.4 & 7.00
\end{tabular} & 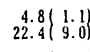 \\
\hline$\neq \underset{O O S}{O O O S}$ & $\begin{array}{r}6.8 \\
25.6\end{array}\left(\begin{array}{l}0.7 \\
7.6\end{array}\right)$ & $\begin{array}{l}10.8(1.0) \\
42.8(11.7)\end{array}$ & $\begin{array}{r}8.2(1.6) \\
32.4(9.1)\end{array}$ & $\left.\begin{array}{rr|r}9.8 & 1 \cdot 1 \\
30.2 & 9.7\end{array}\right)$ & $\begin{array}{c}6.8(0.9) \\
36.8(14.1\end{array}$ \\
\hline$f \begin{array}{lll}0 & O S \\
D & L & L\end{array}$ & $\begin{array}{r}8.4\left(\begin{array}{l}0.9 \\
32.0(14.4)\end{array}\right)\end{array}$ & $\begin{array}{l}10.2(1.2) \\
50.6(22.5)\end{array}$ & $\begin{array}{r}9.8(1.2) \\
45.2(13.2)\end{array}$ & $\begin{array}{l}10.6 \\
39.0\end{array}\left(\begin{array}{ll}18.1 \\
18\end{array}\right)$ & $\begin{array}{c}8.2(0.7) \\
47.2(21.3)\end{array}$ \\
\hline \# $\begin{array}{c}0 \\
0\end{array}$ & $\left.\begin{array}{r}7.0 \\
10.8 \\
10.0 \\
2.6\end{array}\right)$ & $\begin{array}{ccc}10.0 & 2.77 \\
14.8 & (4.0)\end{array}$ & $\begin{array}{r}7.8(3.18) \\
10.6 \\
2.8\end{array}$ & $\begin{array}{r}7.8 \\
11.6\end{array}\left(\begin{array}{l}2.4 \\
2.3\end{array}\right)$ & $\begin{array}{l}6.2 \\
9.4 \\
9.4 .6\end{array}$ \\
\hline
\end{tabular}

注）表 3 注態照

unit:mV'ms

( ): SD

表 5 発音前における表情妫解放電持結時問の $\mathrm{t}$ 一検定結果

\begin{tabular}{|c|c|c|c|c|c|c|c|c|}
\hline \multirow{2}{*}{$\begin{array}{l}\text { 被娭等 } \\
\text { Sound } \\
\end{array}$} & \multicolumn{4}{|c|}{$00 \mathrm{~S}$} & \multicolumn{4}{|c|}{ DLI } \\
\hline & After & 3days & 7 days & 14days & After & 3days & 7 days & 14days \\
\hline x & + & - & - & - & + & - & - & - \\
\hline$=$ & + & + & + & - & + & + & + & - \\
\hline E & + & - & - & - & + & - & - & - \\
\hline 5 & + & + & + & - & + & + & + & - \\
\hline$\neq$ & + & + & + & - & + & + & + & - \\
\hline$F$ & + & + & + & - & + & + & + & - \\
\hline サ & + & + & - & - & + & + & - & - \\
\hline
\end{tabular}

注）表 2 おひ3誉照

表 6 発音前における表情施筋活動量の $\mathrm{t}$ 一检定結果

\begin{tabular}{|c|c|c|c|c|c|c|c|c|}
\hline \multirow{2}{*}{ 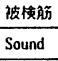 } & \multicolumn{4}{|c|}{$00 \mathrm{~S}$} & \multicolumn{4}{|c|}{ DLI } \\
\hline & After & 3days & 7 days & 14days & After & 3days & 7days & 14days \\
\hline ス & + & - & - & - & + & + & - & - \\
\hline$\equiv$ & + & + & - & - & + & + & - & - \\
\hline E & + & - & - & - & + & + & - & - \\
\hline & + & - & - & - & + & + & - & - \\
\hline$\neq$ & + & + & + & - & + & + & + & - \\
\hline チ & + & + & + & - & + & + & + & - \\
\hline サ & + & - & - & - & + & - & - & - \\
\hline
\end{tabular}

表 7 発音前における $\mathrm{P}_{3}$ の舌接触持綕時問

\begin{tabular}{|c|c|c|c|c|c|}
\hline Sound & Before & After & 3days & 7days & 14days \\
\hline x & $62.9(31.4)$ & $141.6(87.9)$ & $70.0(49.5)$ & $55.7(29.3)$ & $59.7(34.6)$ \\
\hline$\equiv$ & $95.4(30.1)$ & $166.9(109.9)$ & $71.3(29.9)$ & $85.4(32.8)$ & $76.5(39.1)$ \\
\hline$E$ & $121.7(42.1)$ & $146.9(100.0)$ & $145.0(34.7)$ & $128.4(91.9)$ & $120.0(70.2)$ \\
\hline$\equiv$ & $0.01 \quad 0.0)$ & $149.1(91.6)$ & $0.0(0.0)$ & $0.0(0.0)$ & $0.010 .0)$ \\
\hline 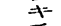 & $174.2(25.6)$ & $185.4(81.0)$ & $188.2(81.3)$ & $172.6(63.4)$ & $161.3(55.0)$ \\
\hline チ் & $166.1(22.8)$ & $227.3(96.8)$ & $192.2(71.2)$ & $167.0(34.9)$ & $160.0(21.1)$ \\
\hline$\because$ & $63.6(14.8)$ & $171.2(58.0)$ & $149.0(103.1)$ & $0.0\left(\begin{array}{ll}0.0 \\
0\end{array}\right)$ & $0.0(0.0)$ \\
\hline
\end{tabular}

表 8 発音前における $\mathrm{P}_{3}$ の舌仕量

\begin{tabular}{|c|c|c|c|c|c|}
\hline Sound & Before & After & 3days & 7 days & 14days \\
\hline x & $40.1(27.9)$ & $979.0(574.5)$ & $407.4(348.8)$ & $156.6(52.5)$ & $158.3(136.8)$ \\
\hline$\equiv$ & $308.9(154.7)$ & $854.5(593.7)$ & $315.5(142.2)$ & $367.8(107.3)$ & $342.4(260.4)$ \\
\hline$E$ & $1537.1(948.8)$ & $3412.5(3309.3)$ & $1867.3(1134.7)$ & $1292.1(1072.7)$ & $1497.5(673.9)$ \\
\hline 5 & $0.0(0.0)$ & $605.9(328.6)$ & $0.0(\quad 0.0)$ & $0.01 \quad 0.0)$ & $0.0(0.0)$ \\
\hline$=1=$ & $2052.5(1115.2)$ & $2472.5(1215.9)$ & $2597.7(1337.4)$ & $2154.4(1126.4)$ & $2253.0(1608.1)$ \\
\hline$-x$ & $1280.5(597.8)$ & $3223.6(2818.6)$ & $2062.1(1245.0)$ & $1877.5(795.4)$ & $1605.5(716.4)$ \\
\hline$\because$ & $97.9(37.1)$ & $1464.5(890.6)$ & $851.3(689.3)$ & $0.010 .0)$ & $0.0(0.0)$ \\
\hline
\end{tabular}

表 9 発音前における $\mathrm{P}_{\mathrm{s}}$ の舌接触持続時問の $\mathrm{t}$ 一検定結果

\begin{tabular}{ccccc}
\hline Sound & After & 3days & 7days & 14 days \\
\hline ス & + & - & - & - \\
ヒ & + & + & - & - \\
キ & - & - & - & - \\
チ & - & - & - & - \\
サ & + & - & - & - \\
\hline
\end{tabular}

注）表 2 および 7 注参照

表10 発音前における $\mathrm{P}_{3}$ の舌圧量の $\mathrm{t}$-検定結果

\begin{tabular}{ccccc}
\hline \hline Sound & After & 3days & 7days & 14days \\
\hline ス & + & + & + & + \\
ヒ & + & - & - & - \\
† & + & - & - & - \\
$\neq$ & - & - & - & - \\
チ & + & + & + & - \\
+ & + & + & & \\
\hline
\end{tabular}

注）表 2 および 7 注参照 
4）発音前の舌筋筋放電活動

発音前の筋放電持続時間および筋活動量の成 績は表11および12, 各被㭘音の装着前後の $\mathrm{t}$ 一検 定結果は表13および14に示した.

笳放電持続時間では，Beforeに比して，「うは Afterから同程度であり，他の被検音はAfterで有 意に延長し、「ス」,「耴および「サ」は 3 日後に，他の 被検音は14日後に同程度を示した。

笳活動量では，全被検音はAfterで有意に增加 し、「耴と「サ」 3 日後。他の被㭘音はほとんど7 日後に同程度を示した。

\section{5）発音前の舌運動}

発音前の舌運動時間および舌運動量の成績は 表 15 よび16, 各被㭘音の装着前後の $\mathrm{t}$ 一检定結 果は表17および18に示した。

舌運動時間では，Beforeに比して，各軸の全被 検音は 3 日後まで有意な延長を示し，ほぼ14日後 で同程度を示した。

舌運動量では, 各軸の全被検音はほぼ 3 日後ま で有意な增加を示し、ほほ14日後において同程度 を示した。

\section{6）発音前の下頻運動}

発音前の下额運動時間および下䪽運動量の成

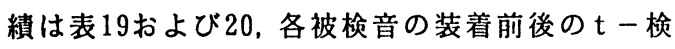
定結果はそれぞれ表21および22に示した。

下䫑運動時間では，Beforeに比して，各軸の全 被梌音は 3 日後まで有意な延長を示し，14日後に 同程度を示した。

下影運動量では，各軸の全被㭘音はほぼ 3 日後 まで有意な增加を示し、Y軸の全被検音はほほ7 日後に同程度を示した。

表11 発音前における舌肪能放電持続時間

\begin{tabular}{|c|c|c|c|c|c|}
\hline Sound & Before & After & 3days & 7 days & 14days \\
\hline ス & $205.7(24.4)$ & $269.7(40.8)$ & $232.1(55.3)$ & $217.6(32.8)$ & $211.7(32.3)$ \\
\hline$\equiv$ & $198.0(20.9)$ & $278.5(31.1)$ & $240.9(28.9)$ & $243.3(25.1)$ & $215.6(28.8)$ \\
\hline$E$ & $209.6(30.7)$ & $256.0(62.0)$ & $220.8(34.6)$ & 229.9 ( 35.3) & $215.7(24.1)$ \\
\hline 戸 & $213.7(28.4)$ & $228.7(48.6)$ & $222.1(33.4)$ & 223.9 ( 36.6 ) & $217.1(24.8)$ \\
\hline$\neq$ & $204.3(42.0)$ & $311.1(45.2)$ & $252.7(34.9)$ & $266.8(25.3)$ & $216.8(20.2)$ \\
\hline チ & $228.9(39.5)$ & $290.8(41.5)$ & $273.6(37.9)$ & $267.1(19.4)$ & $231.7(22.3)$ \\
\hline サ & $214.3(25.9)$ & $244.4(18.3)$ & $234.7(28.6)$ & $221.1(32.8)$ & $232.7(25.8)$ \\
\hline
\end{tabular}

unit : : ss
表12 発音前における舌筋肪活動量

\begin{tabular}{|c|c|c|c|c|c|}
\hline Sound & Before & After & 3days & 7days & 14days \\
\hline z & $14.3(7.4)$ & $22.7(9.2)$ & $30.4(15.4)$ & $15.1(5.8)$ & $19.6(9.8)$ \\
\hline$\equiv$ & $12.5(6.3)$ & $20.6(10.9)$ & $20.9(8.9)$ & $11.9(4.0)$ & $16.3(7.3)$ \\
\hline E & $20.6(13.1)$ & $29.7(9.9)$ & $28.2(12.5)$ & $18.6(\quad 7.3)$ & $22.4(8.6)$ \\
\hline$\doteqdot$ & $24.4(8.9)$ & $37.5(19.9)$ & $35.4(12.0)$ & $35.1(21.3)$ & $25.8(12.8)$ \\
\hline$F$ & $23.1(6.5)$ & $33.7(13.3)$ & $29.9(9.3)$ & $24.7\left(\begin{array}{ll}2.7 \\
)\end{array}\right)$ & $23.2(8.7)$ \\
\hline チ & $9.2(4.1)$ & $21.7(17.4)$ & $15.7(6.4)$ & $13.6(3.1)$ & 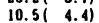 \\
\hline 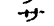 & $19.5(8.3)$ & $28.2(12.8)$ & $20.2(11.3)$ & $20.8(6.8)$ & $23.0(7.6)$ \\
\hline
\end{tabular}

表13発音前における舌舫肪放電持続時問の $\mathrm{t}$ - 検定結果

\begin{tabular}{ccccc}
\hline \hline Sound & After & 3days & 7days & 14days \\
\hline Z & + & - & - & - \\
E & + & + & + & - \\
E & + & - & - & - \\
$\neq$ & + & - & - & - \\
F & + & + & + & - \\
+ & + & + & + & - \\
\hline
\end{tabular}

注）表 2 注参照

表14 発音前における舌肪觔活動量の $\mathrm{t}$ 一検定結果

\begin{tabular}{ccccc}
\hline \hline Sound & After & 3days & 7days & 14days \\
\hline ス & + & + & - & - \\
E & + & + & - & - \\
F & + & - & - & - \\
f & + & + & - & - \\
サ & + & + & - & - \\
\hline
\end{tabular}

注）表 2 注参照

表15 発音前における舌運動時間

\begin{tabular}{|c|c|c|c|c|c|c|}
\hline Sound & Axis & Before & After & 3days & 7days & 14days \\
\hline z & $\begin{array}{l}X \\
Y \\
Z\end{array}$ & $\begin{array}{l}210.1(30.5) \\
205.9(28.8) \\
224.0(30.8)\end{array}$ & $\begin{array}{l}269.2(29.1) \\
267.1(38.6) \\
286.5(36.5)\end{array}$ & 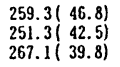 & $\begin{array}{l}219.5(26.0) \\
211.2(24.4) \\
236.4(31.5)\end{array}$ & $\begin{array}{l}218.7(15.9) \\
208.7(16.4) \\
227.7(19.9)\end{array}$ \\
\hline$=$ & $\begin{array}{l}X \\
Y \\
Z\end{array}$ & $\begin{array}{l}197.5(21.0) \\
207.3(33.1) \\
210.8(17.8)\end{array}$ & $\begin{array}{l}272.9(21.9) \\
268.5(23.6) \\
288.9(24.0)\end{array}$ & $\begin{array}{l}253.5(34.2) \\
246.9(33.1) \\
262.5(33.8)\end{array}$ & $\begin{array}{l}232.8(23.2) \\
224.1(24.3) \\
244.7(23.5)\end{array}$ & $\begin{array}{l}221.2(27.7) \\
216.0(24.7) \\
230.9(25.2)\end{array}$ \\
\hline E & $\begin{array}{l}X \\
Y \\
Z\end{array}$ & $\begin{array}{l}200.8(22.7) \\
193.5(24.5) \\
208.7(31.9)\end{array}$ & $\begin{array}{l}278.0(29.6) \\
268.1(29.3) \\
286.7(25.9)\end{array}$ & $\begin{array}{l}242.7(38.1) \\
232.3(39.7) \\
253.1(35.6)\end{array}$ & $\begin{array}{l}214.5(23.2) \\
207.3(20.4) \\
235.6(24.2)\end{array}$ & $\begin{array}{l}207.7(16.5) \\
203.7(19.3) \\
220.7(20.8)\end{array}$ \\
\hline 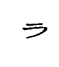 & $\begin{array}{l}X \\
Y \\
Z\end{array}$ & $\begin{array}{l}200.1(16.4) \\
203.5(21.7) \\
219.7(20.8)\end{array}$ & $\begin{array}{l}295.1(42.5) \\
286.5(47.7) \\
304.3(37.8)\end{array}$ & $\begin{array}{l}268.0(36.5) \\
261.1(39.5) \\
272.8(40.7)\end{array}$ & $\begin{array}{l}221.7(32.7) \\
215.7(35.7) \\
231.5(31.6)\end{array}$ & $\begin{array}{l}188.7(41.4) \\
185.5(40.2) \\
202.4(42.8)\end{array}$ \\
\hline$\neq$ & $\begin{array}{l}X \\
Y \\
Z\end{array}$ & $\begin{array}{l}198.0(14.1) \\
201.3(19.6) \\
224.3(23.0)\end{array}$ & $\begin{array}{l}270.7(24.1) \\
266.1(27.8) \\
294.7(27.8)\end{array}$ & $\begin{array}{l}253.3(35.2) \\
251.9(32.5) \\
267.6(35.6)\end{array}$ & $\begin{array}{l}229.3(18.4) \\
221.7(18.0) \\
243.2(22.1)\end{array}$ & $\begin{array}{l}203.2(13.9) \\
200.4(17.4) \\
218.9(21.9)\end{array}$ \\
\hline チ & $\begin{array}{l}X \\
Y \\
Z\end{array}$ & $\begin{array}{l}199.1(25.1) \\
196.7(25.5) \\
214.5(24.0)\end{array}$ & $\begin{array}{l}298.7(39.6) \\
290.5(37.2) \\
315.9(41.7)\end{array}$ & $\begin{array}{l}252.3(27.6) \\
248.5(30.1) \\
265.9(28.5)\end{array}$ & $\begin{array}{l}223.1(25.6) \\
215.5(23.0) \\
233.6(29.3)\end{array}$ & $\begin{array}{l}213.9(25.3) \\
209.1(26.3) \\
244.0(25.0)\end{array}$ \\
\hline サ & $\begin{array}{l}X \\
Y \\
Z\end{array}$ & $\begin{array}{l}193.1(20.1) \\
190.7(20.4) \\
206.5(18.9)\end{array}$ & $\begin{array}{l}263.1(28.9) \\
254.8(23.7) \\
274.8(25.2)\end{array}$ & $\begin{array}{l}221.6(26.5) \\
216.4(29.0) \\
232.5(31.2)\end{array}$ & $\begin{array}{l}228.8(24.2) \\
217.2(23.8) \\
238.1(24.8)\end{array}$ & $\begin{array}{l}209.3(29.2) \\
200.9(30.3) \\
222.8(36.0)\end{array}$ \\
\hline
\end{tabular}

$\stackrel{\text { unit }: \text { ms }}{(1): S D}$ 


\section{IV.考察}

\section{1.実䓉的局部口蓋床について}

日常臨床では, 社会保険・老人保健診療の占め る役割は大きい21). 局部床義歯の設計に関して極 めて有利な金属床は, この社会保險・老人保健診 療制度では認められてなく，日本独特の設計を生 み出している.また。これらはは歯科医学教育に も影響を与え，その結果として21大学中 12 大学が 局部床義菌学の実習にパラタルパーあるいはリ ンガルバーの屈曲を夹習項目に举げている到.

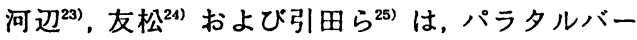
の走行位置とその形態が調音機能へ与える影響 について、ソナグラムを用いて音箁学的に検索し た.そこで著者らは,パラタルバーの走行位䀦が 調音機能へ与える影響を各調音器官の機能とし て，筋電図学的には表情竻および舌筋筋放電活動， 運動学的には舌および下频運動, 力学的には舌圧 について，経日的検索を行った。

実験的局部口蓋休の形態を決定する際には，前， 中および後パラタルパーのいずれも使用される 両侧の第二小曰蒾，第一および第二大四歯欠損の 両㑬遊雍端局部床義霆を想定した。この局部床義 雬は,大連結子にコバルトクロム合金による畞製 パラタルバー，維持装置に雨侧第一小曰歯にRPI クラスプ，人工歯および義畨床からなる．中パラ 床は，義菌床およびパラタルバーから楧成され，

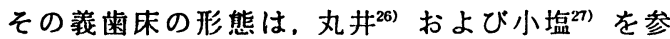
考に口蓋幅径の $1 / 6$ とし上頻結節を覆う範囲とし た。

中パラタルバーの走行位置については, 引田 ${ }^{25)}$ と同様に両侧第二小四㐘を結ふ線上とした。また， パラタルバーとロ蓋粘膜とのリリーフは, 藍ら ${ }^{22)}$ を参考に約 $0.5 \mathrm{~mm}$ とした。

中パラ床の義菌床と中パラタルバーの調製は， 圧力センサ設置の操作性などを考慮し，加熱重合 型義茵床用レジンを用いた。しかし中パラタルバー を加熱重合型義歯床用レジンで調製することで， 金属製パラタルバーとの舌感が異なることが稀 念される.そこで表面粗さ（JIS規格10点平均粗 さ）で比較すると, 山本 ${ }^{28)}$ は加熱重合型義歯床用 レジンのそれは，バフを用いた最終研磨で $0.1 \mu \mathrm{m}$,

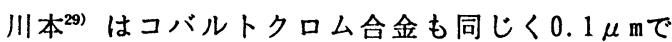
あったと報告している，最終研磨によって，両材
表16 発音前における舌通動量

\begin{tabular}{|c|c|c|c|c|c|c|}
\hline Sound & Axis & Before & After & 3 days & 7days & 14days \\
\hline z & $\begin{array}{l}\mathrm{X} \\
\mathrm{Y} \\
\mathrm{Z}\end{array}$ & $\begin{array}{r}71.6(9.6) \\
66.1(6.8) \\
170.1(27.2)\end{array}$ & $\begin{array}{r}97 \\
122 \\
250\end{array}$ & $\begin{array}{r}95.7(7.1) \\
71.8(9.6) \\
195.0(24.5)\end{array}$ & $\begin{array}{r}63.2(13.3) \\
87.6(16.6) \\
184.0(17.8)\end{array}$ & $\begin{array}{r}62.3(13.6) \\
60.0(13.3) \\
170.0(17.2)\end{array}$ \\
\hline$\equiv$ & $\begin{array}{l}X \\
Y \\
Z\end{array}$ & $\begin{array}{l}45.5(15.5) \\
30.8(6.8) \\
91.2(25.5)\end{array}$ & $\begin{array}{r}60.4(14.3) \\
51.0(12.9) \\
161.7(17.2)\end{array}$ & $\begin{array}{r}61.0(16.0) \\
57.0(14.5) \\
123.5(23.7)\end{array}$ & $\begin{array}{r}47.0(12.0) \\
47.5(14.9) \\
137.1(21.9)\end{array}$ & $\begin{array}{l}48.4(14.3) \\
30.8(18.7) \\
92.9(25.4)\end{array}$ \\
\hline E & $\begin{array}{l}\mathrm{X} \\
\mathrm{Y} \\
\mathrm{Z}\end{array}$ & $\begin{array}{r}46.4(24.9) \\
38.1(21.3) \\
120.0(21.7)\end{array}$ & $\begin{array}{r}69.2(29.0) \\
56.1(19.8) \\
229.3(23.5)\end{array}$ & $\begin{array}{r}87.8(19.9) \\
88.3(37.7) \\
231.2(42.5)\end{array}$ & $\begin{array}{r}54.2(12.4) \\
75.3(19.2) \\
191.5(27.7)\end{array}$ & $\begin{array}{r}71.0(16.7) \\
87.7(26.4) \\
151.3(26.6)\end{array}$ \\
\hline$\equiv$ & $\begin{array}{l}X \\
Y \\
Z\end{array}$ & $\begin{array}{r}129.1(26.9) \\
72.7(24.7) \\
155.7(22.9)\end{array}$ & $\begin{array}{r}229.8(22.5) \\
95.8(23.5) \\
269.4(46.0)\end{array}$ & $\begin{array}{r}193.4(35.3) \\
86.0(31.2) \\
209.7(32.2)\end{array}$ & $\begin{array}{r}128.7(26.7) \\
72.8(19.1) \\
172.3(29.9)\end{array}$ & $\begin{array}{r}123.9(21.4) \\
74.5(17.6) \\
162.2(12.8)\end{array}$ \\
\hline$=$ & $\begin{array}{l}X \\
Y \\
Z\end{array}$ & $\begin{array}{r}115.6(18.4) \\
54.1(13.9) \\
202.7(42.0)\end{array}$ & $\begin{array}{r}159.7(14.1) \\
86.1(18.9) \\
286.3(26.6)\end{array}$ & $\begin{array}{r}163.7(32.5) \\
75.6(13.5) \\
227.7(38.7)\end{array}$ & $\begin{array}{r}105.7(27.4) \\
69.9(18.4) \\
192.2(22.1)\end{array}$ & $\begin{array}{r}114.6(17.9) \\
57.7(19.5) \\
213.7(39.3)\end{array}$ \\
\hline チ & $\begin{array}{l}X \\
Y \\
Z\end{array}$ & $\begin{array}{r}106.1(29.3) \\
28.4(9.6) \\
120.0(19.6)\end{array}$ & $\begin{array}{r}145.4(29.4) \\
39.9(14.2) \\
250.2(23.4)\end{array}$ & $\begin{array}{r}104.9(29.2) \\
27.2(14.8) \\
162.9(21.4)\end{array}$ & $\begin{array}{r}95.7(19.7) \\
24.6(12.0) \\
161.1(21.0)\end{array}$ & $\begin{array}{r}106.8(15.8) \\
25.5(11.2) \\
140.5(25.7)\end{array}$ \\
\hline サ & $\begin{array}{l}X \\
Y \\
Z\end{array}$ & $\begin{array}{r}43.1(13.7) \\
26.8(14.8) \\
101.5(15.2)\end{array}$ & $\begin{array}{r}83.6(16.6) \\
86.1(11.1) \\
255.9(28.1)\end{array}$ & $\begin{array}{r}55.8(13.4) \\
70.5(25.1) \\
266.1(39.2)\end{array}$ & $\begin{array}{r}50.0(27.4) \\
30.5(12.4) \\
124.9(28.6)\end{array}$ & $\begin{array}{r}47.0(17.6) \\
29.9(11.8) \\
100.1(21.8)\end{array}$ \\
\hline
\end{tabular}

unit : 1 : $:$ SD $m$

表17 発音前における舌運動洔間の $\mathrm{t}$ 一検定結果

\begin{tabular}{|c|c|c|c|c|c|c|c|c|c|c|c|c|}
\hline \multirow{2}{*}{\multicolumn{2}{|c|}{$\frac{\text { Axis }}{\text { Sound After }}$}} & \multicolumn{3}{|c|}{ X铀 } & \multicolumn{4}{|c|}{$Y$ on } & \multicolumn{4}{|c|}{$\mathrm{z}$} \\
\hline & & 3days & 7 days & 14 diays & After & 3days & 7days & 14kiens & After & 3days & Tdays & 14tays \\
\hline$\pi$ & + & + & - & - & + & + & - & - & + & + & - & - \\
\hline シ & + & + & + & + & + & + & - & - & + & + & + & + \\
\hline t & + & + & - & - & + & + & - & - & + & + & + & - \\
\hline$\Rightarrow$ & + & + & + & - & + & + & - & - & + & + & - & - \\
\hline$\neq$ & + & + & + & - & + & + & + & - & + & + & + & - \\
\hline f & + & + & + & - & + & + & + & - & + & + & - & - \\
\hline サ & + & + & + & - & + & + & + & - & + & + & + & - \\
\hline
\end{tabular}

表18 発音前における舌運動量の $\mathrm{t}$ 一検定結果

\begin{tabular}{|c|c|c|c|c|c|c|c|c|c|c|c|c|}
\hline \multirow{2}{*}{\multicolumn{2}{|c|}{$\begin{array}{l}\text { Axis } \\
\text { Sound After }\end{array}$}} & \multicolumn{3}{|c|}{$x$} & \multicolumn{4}{|c|}{ Y } & \multicolumn{4}{|c|}{20} \\
\hline & & 3days & 7days & 14days & After & 3 days & 7 days & 14days & After & 3days & 7 days & Iddays \\
\hline z & + & + & - & - & + & + & - & - & + & + & - & - \\
\hline シ & + & + & - & - & + & + & - & - & + & + & + & - \\
\hline$t$ & + & + & + & - & + & + & + & + & + & + & + & + \\
\hline j & + & + & - & - & + & - & - & - & + & + & - & - \\
\hline$\neq$ & + & + & - & - & + & + & + & - & + & + & - & - \\
\hline 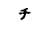 & + & - & - & - & + & - & - & - & + & + & + & + \\
\hline$\forall$ & + & + & - & - & + & + & - & - & + & + & + & - \\
\hline
\end{tabular}


表19 発音前における下颚運動時間

\begin{tabular}{|c|c|c|c|c|c|c|}
\hline Sound & Axis & Before & After & 3 days & 7 diays & 14days \\
\hline x & $\begin{array}{l}X \\
Y \\
Z\end{array}$ & $\begin{array}{l}200.1(23.0) \\
198.6(22.1) \\
212.9(25.5)\end{array}$ & $\begin{array}{l}263.3(35.3) \\
253.2(36.7) \\
272.1(38.2)\end{array}$ & $\begin{array}{l}260.1(20.6) \\
253.2(18.5) \\
269.9(23.1)\end{array}$ & $\begin{array}{l}206.3(27.5) \\
199.6(24.9) \\
216.7(30.6)\end{array}$ & $\begin{array}{l}207.1(29.7) \\
199.2(24.4) \\
214.1(29.1)\end{array}$ \\
\hline$\equiv$ & $\begin{array}{l}X \\
Y \\
Z\end{array}$ & $\begin{array}{l}134.9(22.7) \\
182.3(20.5) \\
195.6(24.4)\end{array}$ & $\begin{array}{l}268.5(24.2) \\
261.1(23.9) \\
278.3(25.2)\end{array}$ & $\begin{array}{l}248.0(26.1) \\
240.5(21.3) \\
259.6(22.7)\end{array}$ & $\begin{array}{l}228.8(36.2) \\
218.9(30.2) \\
235.1(37.3)\end{array}$ & $\begin{array}{l}202.7(28.7) \\
193.6(25.0) \\
214.5(28.9)\end{array}$ \\
\hline E & $\begin{array}{l}X \\
Y \\
Z\end{array}$ & $\begin{array}{l}200.1(21.4) \\
192.0(20.9) \\
208.4(23.7)\end{array}$ & $\begin{array}{l}273.3(25.4) \\
254.9(25.5) \\
284.0(25.3)\end{array}$ & $\begin{array}{l}244.4(26.2) \\
234.7(26.3) \\
256.9(20.8)\end{array}$ & $\begin{array}{l}208.4(17.6) \\
200.8(18.6) \\
221.2(26.2)\end{array}$ & $\begin{array}{l}206.4(19.8) \\
196.0(15.6) \\
220.7(26.4)\end{array}$ \\
\hline$\overline{7}$ & $\begin{array}{l}X \\
Y \\
Z\end{array}$ & $\begin{array}{l}188.7(21.8) \\
178.5(21.6) \\
202.4(20.6)\end{array}$ & $\begin{array}{l}260.8(36.9) \\
252.4(35.0) \\
266.9(44.6)\end{array}$ & $\begin{array}{l}245.5(41.4) \\
238.0(37.6) \\
253.2(45.8)\end{array}$ & $\begin{array}{l}214.7(22.5) \\
212.0(23.1) \\
205.7(27.3)\end{array}$ & $\begin{array}{l}203.3(20.3) \\
197.7(18.0) \\
212.9(20.8)\end{array}$ \\
\hline$\neq$ & $\begin{array}{l}X \\
Y \\
Z\end{array}$ & $\begin{array}{l}196.1(13.8) \\
190.3(15.1) \\
214.9(19.3)\end{array}$ & $\begin{array}{l}283.5(35.4) \\
274.0(36.6) \\
302.8(30.0)\end{array}$ & $\begin{array}{l}266.9(24.7) \\
264.1(22.8) \\
290.7(28.4)\end{array}$ & $\begin{array}{l}251.2(35.6) \\
241.6(37.2) \\
262.0(29.8)\end{array}$ & $\begin{array}{l}193.2(12.6) \\
204.3(14.4) \\
223.3(22.1)\end{array}$ \\
\hline チ & $\begin{array}{l}X \\
Y \\
Z\end{array}$ & $\begin{array}{l}194.5(14.7) \\
190.8(17.2) \\
204.0(14.1)\end{array}$ & $\begin{array}{l}278.3(30.5) \\
268.5(29.2) \\
288.8(30.6)\end{array}$ & $\begin{array}{l}255.4(26.1) \\
250.1(27.6) \\
260.9(25.1)\end{array}$ & $\begin{array}{l}233.7(27.5) \\
228.0(27.7) \\
247.6(31.6)\end{array}$ & $\begin{array}{l}222.8(39.0) \\
215.7(42.4) \\
234.4(43.6)\end{array}$ \\
\hline サ & $\begin{array}{l}X \\
Y \\
Z\end{array}$ & $\begin{array}{l}190.5(14.8) \\
186.0(17.4) \\
202.5(15.2)\end{array}$ & $\begin{array}{l}263.6(25.3) \\
258.4(24.1) \\
277.1(23.3)\end{array}$ & $\begin{array}{l}241.9(35.5) \\
234.5(34.7) \\
254.7(42.7)\end{array}$ & $\begin{array}{l}212.1(25.1) \\
207.5(23.7) \\
225.6(23.8)\end{array}$ & $\begin{array}{l}206.5(29.1) \\
200.5(26.5) \\
218.1(30.3)\end{array}$ \\
\hline
\end{tabular}

表20 発音前における下颣通動量

\begin{tabular}{|c|c|c|c|c|c|c|}
\hline Sound & Axis & Before & After & 3days & 7 days & 14days \\
\hline x & $\begin{array}{l}\mathrm{X} \\
\mathrm{Y} \\
\mathrm{Z}\end{array}$ & $\begin{array}{l}27.8(9.1) \\
21.1(14.4) \\
82.7(19.1)\end{array}$ & $\begin{array}{r}46.7(13.2) \\
42.9(13.0) \\
134.3(25.6)\end{array}$ & $\begin{array}{l}49.6(22.1) \\
39.6(14.0) \\
88.1(38.1)\end{array}$ & $\begin{array}{l}35.0(13.3) \\
27.5(14.3) \\
79.9(32.1)\end{array}$ & $\begin{array}{l}34.9(14.1) \\
25.6(12.0) \\
70.2(19.6)\end{array}$ \\
\hline$=$ & $\begin{array}{l}X \\
Y \\
Z\end{array}$ & $\begin{array}{l}32.7(17.0) \\
23.7(12.0) \\
54.4(14.8)\end{array}$ & $\begin{array}{l}43.7(14.0) \\
51.7(29.9) \\
82.6(16.8)\end{array}$ & $\begin{array}{l}55.1(32.3) \\
45.3(37.4) \\
82.5(15.8)\end{array}$ & $\begin{array}{l}51.1(21.6) \\
29.0(7.9) \\
75.2(14.9)\end{array}$ & $\begin{array}{l}46.9(13.7) \\
28.6(12.3) \\
66.9(15.4)\end{array}$ \\
\hline E & $\begin{array}{l}X \\
Y \\
Z\end{array}$ & $\begin{array}{r}72.5(18.4) \\
38.9(17.0) \\
116.3(27.9)\end{array}$ & $\begin{array}{r}127.7(25.6) \\
70.5(14.5) \\
294.9(31.1)\end{array}$ & $\begin{array}{r}101.6(29.3) \\
56.9(24.6) \\
255.3(36.1)\end{array}$ & $\begin{array}{r}61.0(17.6) \\
34.5(15.2) \\
183.4(21.5)\end{array}$ & $\begin{array}{r}78.4(20.9) \\
46.1(23.5) \\
208.3(22.3)\end{array}$ \\
\hline $\Rightarrow$ & $\begin{array}{l}\mathrm{X} \\
\mathrm{Y} \\
\mathrm{Z}\end{array}$ & $\begin{array}{r}65.1(13.4) \\
41.6(15.8) \\
119.9(23.2)\end{array}$ & $\begin{array}{r}194.7(22.5) \\
78.8(25.2) \\
287.0(45.1)\end{array}$ & $\begin{array}{r}169.3(18.6) \\
69.0(15.0) \\
236.9(44.6)\end{array}$ & $\begin{array}{r}118.3(29.7) \\
42.2(18.6) \\
114.4(31.1)\end{array}$ & $\begin{array}{r}56.5(17.4) \\
38.9(12.7) \\
114.6(25.4)\end{array}$ \\
\hline$\neq$ & $\begin{array}{l}X \\
Y \\
Z\end{array}$ & $\begin{array}{l}46.2(13.5) \\
35.2(16.1) \\
90.6(21.9)\end{array}$ & $\begin{array}{r}94.5(19.3) \\
64.6(25.6) \\
180.8(25.4)\end{array}$ & $\begin{array}{r}83.5(19.1) \\
80.7(25.8) \\
197.3(31.2)\end{array}$ & $\begin{array}{r}88.2(16.2) \\
49.6(12.0) \\
125.6(28.4)\end{array}$ & $\begin{array}{r}58.3(15.9) \\
35.7(19.9) \\
108.1(27.4)\end{array}$ \\
\hline$F$ & $\begin{array}{l}X \\
Y \\
Z\end{array}$ & $\begin{array}{l}41.1(19.0) \\
30.1(18.0) \\
56.6(29.0)\end{array}$ & $\begin{array}{r}94.3(16.9) \\
83.3(16.1) \\
107.1(29.9)\end{array}$ & $\begin{array}{l}56.1(11.9) \\
52.9(13.5) \\
93.0(16.3)\end{array}$ & $\begin{array}{l}55.5(14.2) \\
42.3(22.0) \\
70.7(15.5)\end{array}$ & $\begin{array}{l}65.3(15.3) \\
42.9(35.0) \\
58.7(26.0)\end{array}$ \\
\hline サ & $\begin{array}{l}X \\
Y \\
Z\end{array}$ & $\begin{array}{r}39.3(19.6) \\
30.1(13.3) \\
127.5(32.0)\end{array}$ & $\begin{array}{r}62.9(17.4) \\
52.1(18.4) \\
175.7(27.5)\end{array}$ & $\begin{array}{r}42.3(13.5) \\
41.1(12.0) \\
141.4(36.2)\end{array}$ & $\begin{array}{r}34.7(18.1) \\
34.6(15.7) \\
135.2(38.1)\end{array}$ & $\begin{array}{r}27.2(16.2) \\
30.3(16.8) \\
129.0(32.8)\end{array}$ \\
\hline
\end{tabular}

unit : $m \cdot \mathrm{m} \cdot \mathrm{ms}$

料の表面粗さは同様となるとの報告に基つくと， 表面性状による舌感の相違はないものと判断し た。

岡信ら ${ }^{30)}$ の部分床義蒾症例の統計的観察では， パラタルバーの使用は, 中パラタルバーが最も多 かったと報告している．そこで著者らは，3 種の パラタルバーのうち，その第一段階として中パラ タルバーについて検索することとした。
表21 発音前における下频運動洔問の $\mathrm{t}$ 一検定結果

\begin{tabular}{|c|c|c|c|c|c|c|c|c|c|c|c|c|}
\hline \multirow{2}{*}{\multicolumn{2}{|c|}{ Sxis }} & \multicolumn{3}{|c|}{$\mathrm{X}$ 神 } & \multicolumn{4}{|c|}{$Y_{\text {䌷 }}$} & \multicolumn{4}{|c|}{ Z㽘 } \\
\hline & & 3days & 7 diays & 14 days & After & 3days & 7 days & 14diays & After & 3 days & 7thys & 14days \\
\hline$\lambda$ & + & + & - & - & + & + & - & - & + & - & - & - \\
\hline シ & + & + & + & + & + & + & - & - & + & + & + & + \\
\hline t & + & + & + & - & + & + & - & - & + & + & + & + \\
\hline 5 & + & + & - & - & + & + & - & - & + & + & - & - \\
\hline$\neq$ & + & + & + & + & + & + & + & - & + & + & + & + \\
\hline f & + & + & + & + & + & + & - & - & + & + & - & - \\
\hline サ & + & - & - & - & + & - & - & - & + & - & - & - \\
\hline
\end{tabular}

表22 発音前における下䍙䦽動量の $\mathrm{t}$ 一検定結果

\begin{tabular}{|c|c|c|c|c|c|c|c|c|c|c|c|c|}
\hline \multirow{2}{*}{\multicolumn{2}{|c|}{$\frac{\text { Axis }}{\text { Sound afte }}$}} & \multicolumn{3}{|c|}{ x粙 } & \multicolumn{4}{|c|}{ Y th } & \multicolumn{4}{|c|}{ Z曲 } \\
\hline & & 3days & 7days & 14days & After & 3days & ?days & 14 diays & After & 3days & 7 days & 14days \\
\hline 2 & + & + & - & - & + & + & - & - & + & + & - & - \\
\hline シ & + & + & - & - & + & + & - & - & + & + & + & - \\
\hline t & + & + & - & - & + & + & - & - & + & + & - & - \\
\hline ร & + & + & - & - & + & + & - & - & + & + & - & - \\
\hline$\neq$ & + & + & + & - & + & + & + & - & + & + & + & - \\
\hline f & + & + & + & - & + & + & + & - & + & + & + & - \\
\hline+ & + & + & - & - & + & + & - & - & + & + & - & - \\
\hline
\end{tabular}

\section{2.音声継続時間について（表 1 と 2）}

先行子音継続時問では, Beforeに比して, 全被 検音はAfterで有意に延長し「「サ」は 3 日後。「七」，

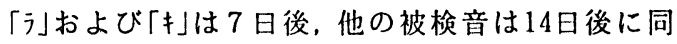
程度を示したこの成綃は，口蓝を全て得う全口 蓋床を用い同様の実験を行って 7 日後に同程度を 示した浜中 ${ }^{15)}$ の報告と異なっている.これらの相 違は口蓋床の形隹と厚さによるものと考えられ， 中パラ床ではその複雑な口蓋形態によって, 調音 機能が中パラ床装着以前に自己補正されるのに より多くの時間を必要としたのではないかと推 察される。

後続母音継続時間では, 全被検音はAfterから 同程度を示した。

この成績は，浜中 ${ }^{15)}$ の成績と一致し、口蓋形態 の変化が後続母音継続時間に与える影響はほと んどないものと推察できる.

3.発音前の表情筋筋放雪活動について（表 3〜 6)

筋放電持続時間では，両被検筋ともに，全被 検音はAfterで有意に延長し，「对および「七」は 3 日後,「州は 7 日後, その他の被検音は14日後に 同程度を示した。これらの成縝は。「入」は 3 日後 に同程度を示し、「打は14日後でも有意に延長し 
たままであった浜中占) の報告と同様な傾向を示 している.このことは，口蓋形態や厚さの相違が， 単音節発音前における口唇の調音機能に大きく 影響を与える被検音とあまり影響を与えない被 検音とがあることを示唆している.

DLIの筋放電持続時間は，OOSに比して, 全被検 音で延長し，その筋放電開始時が早期に行われい た。この成績は，浜中の報告(5) と近似した経日的 変化様相を示したか，浜中占) では「子」は 3 日後に 同程度を示したのに対し，著者らの結果では14日 後に同程度を示した。これらのことは，舌背と苗 頸部との間に狭い間隙を形成する菌擦音である 「子発音が中パラ床を用いた著者らの結果におい て, 歯頸部周辺の口蓋形態の相違の影響を受けて 口唇の調音機能の適応により多くの時間を必要 としたものと推察できる.

筋活助量では，両被榆筋ともに全被検音は, Af ter で有意に增加し，14日後に同程度を示した.これら のことは，中パラ床装着による口蓋形態の変化お よびロ腔内容積減少により, 調音器官に混乱を招 き,その補正として声道の開口端である上下口唇 の笳放電持続時間の延長および筋活動量の增加 により，調音機能の補正を行っているものと推察 できる.

中パラ床の筇活動量における経日的变化様相 は，浜中 ${ }^{15)}$ の報告と比較し，ほほ全被榆音で早期 に同程度を示した。このことは, 全口蓋床と比較 し, 中パラ床は口腔内容積減少が少なく、舌が口 蓋と直接的に接する部分も存在することから，中 パラ床装着の自己補正がより早期に行れるもの と考えられる。

\section{4. 発音前の舌圧について（表 $7 \sim 10 ）$}

発音時に舌が口蓋侧方部に接触することはパ ラトグラムからでも明らかであり, また,口蓋侧 方部の舌接触持続時間および舌圧量ともに最大

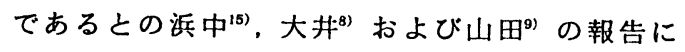
基づき, 口蓋例方部 $\left(\mathrm{P}_{3}\right)$ の成績を検討すること とした。

「う発音時では，著者の成績は口蓋侧方部 $\mathrm{P}_{3}$ で 舌接触を認めず，口蓋床に装着した圧 transducer によって舌圧を求めた島”゙は，設置位置の明記は ないか，口茼侧方部に舌接触を認め，異なってい る.しかし, 正常有歯影者のパラトグラムの森田 ${ }^{3}$ の研究は，著者らの口蓝侧方部 $\left(\mathrm{P}_{3}\right)$ の舌接触は
ないことを裏付けている.

舌接触開始時が早期に行われたことによる舌 接触持続時間の延長は，口腔内容積減少による舌 の調音機能の錯誤が, 舌の $\mathrm{P}_{3}$ への早期接触を誘 いたと推察できる.

中パラ床の舌接触持続時間では,「耴および「キ」 はAfterから同程度を示し，全口蓋㦿では14日後 まで有意に延長していた浜中融の報告と相違して いる.このことは，中パラ床では その構成要素 の一つである義菌床部分の口腔内容積減少が他 の部分より大であるため, 全口蓋床と比較し、口 蓋側方部での口蓋と舌の封銷がより容易に行わ れたためと推察される.

「シ」「耴」よび「执発音時では，これらの舌圧 量は比較的早期に同程度を示した。このことは， 中パラ床がその形隹から口蓋側方部の口些内容 皘減少が他の部位と比して大きいため，口蓋と舌 との閉鎖が重要である「シ」「坆および「キ」発音で 口蓋侧方部の閉鎖が行いやすく，比較的早期に同 程度を示したと考えられる。

「对の舌圧量は14日後でも有意に延長していた のは，舌前部と柬项部との間に，呼気を流失さ せるトンネル状の狭い間隙を形成する摩擦音で ある「ス発音時では，口蓋侧方部での舌圧が有意 に增加し自己補正が困難となり，舌圧量が14日後 にも有意に增加したと推察できる。

\section{5. 発音前の舌筋筋放電活動について（表11〜} 14)

筋放電持続時間では，「うはAf terから同程度で あり，他の被検音は，Beforeに比して，Afterで有 意に延長し，14日後に同程度を示した。

舌前部を口蓋の前方部に反りあげて接触させ, 呼気を一旦せき止めて一気に開放する弾音であ る「う発音時では，舌の微妙な形態変化を必要と しないため中パラ床による影響を受けなかった と推察できる.

「门以外の全被検音がAfterに有意な延長と 14 日後に同程度を示した著者の成績は, 全口蓋床を 用いた萩原 ${ }^{16)}$ の報告之経日的变化様相は近似し ていた.このことは, 発音前の舌筋筋放電活動は 口蓋形態の変化に対し，ほぼ一定自己補正を行う が,その口䓝形態の変化の相違にはあまり影響を 受けないことを示唆している.

筂活動量では, 全被検音はAfterで有意に增加 
し、ほとんど 7 日後に同程度を示した。これらの 中パラ床における舌筋筋活動量の経日的变化様 相は，萩原 ${ }^{16)}$ の報告と近似し，調音動作における 舌筋の適応はほほ７日後に完了することを示唆す している.

\section{6. 発音前の舌運動について（表 15〜 18）}

舌および下䪽の迺動特性について，䓢田 ${ }^{32)}$ 舌 の調音動作を舌全体の移動および舌尖部の形態 变化という 2 種類の運動の合成と見なせると報告 している.

そこで著者らは，舌全体の移動を舌迎動で，舌 尖部の形態变化を舌備筋放電活動で検索するこ ととした。

舌通動時間では, 各軸の全被検音は 3 日後まで 有意に延長し，ほぼ14日後で同程度を示した。 れらの成績は，萩原 ${ }^{16)}$ の報告と一致していた。 と くに、「シ」は，X軸およびZ軸において，14日後 も有意に延長していた。このことは，中パラ床装 着によるロ蓋形態の変化および口䏶内容皘減少 によって，舌と口蓋がより近接する結果，両者間 で微妙な狭い間隙を形成する摩擦音である「シ発 音において，発音前により多くの舌位置決定時間 を要したものと推察できる.

舌運動量では，各軸の全被検音は，ほほ 3 日後 まで有意な增加を示しほほぼ14日後に同程度を示 した。

中パラ床装着後の舌運動量は $Z$ 軸で最も大きく， $\mathrm{X}$ 軸，Y 軸の順に小となる傾向であり，全口蓋床 装着後のそれらは X 軸で最も大きく，Z軸，Y 軸 の順で小となった萩原 ${ }^{16)}$ の報告と相違している. このことは全口蓋床では，上下方向への口些内容 積減少が大きいために，これを㭪償するのに前後 方向への舌運動量の增加によって調音機能の㭪 㑋をしているが，中パラ床では，上下方向への口 胫内容積減少が少ないために，上下方向への舌運 動量增加によって調音機能を補正しているもの と推察される.

さらに舌の調音動作における舌筋筋活動量 と 舌運動量を比較すると，前者がやや早期に適応す る傾向が認められ，舌尖部における形態変化の自 己補正は，舌全体の移動による自己補正よりも早 期に行われることが示唆される。
7. 発音前の下䫟運動について（表19～22）

下影进動時問では，各軸の全被検音は3日後ま で有意な延長を示し，14日後に同程度を示した。 中パラ床装着後の下領運動時間は $\mathrm{Z}$ 軸で最も延 長し，X 軸，Y 軸の順に小となる傾向であり，萩 原 ${ }^{16)}$ の報告と一致した。このことは，下䪽の調音 動作が主に上下運動によって自己補正を行って いることを裹付けている。

舌運動時間と下穎運動時間とを比較すると。そ の経日的变化様相は，ほぼ同様な傾向を示し，中 パラ床装着による共鳴㓐容稍減少およびロ荅形 態の変化を発音前における舌と下額の協調運動 によって㭪偵しているものと推察できる.

下站迅動量では，各軸の全被㭘音はほぼ 3 日後 まで有意な增加を示し，Y軸の全被検音はほぼ7 日後に同程度を示した，

中パラ床装着後の下额運動量は，下额運動時間 と同様に， $\mathrm{Z}$ 軸で最も增加し， $\mathrm{X}$ 軸， $\mathrm{Y}$ 軸の順に 小となる傾向でありこれは，先行子音開始時の

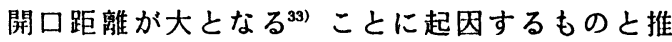
察できる。

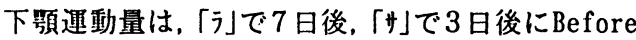
のそれらと同程度を示し，自己㭪正の適応が早期 に行われた。これらのことは、これらの被検音の 後続母音が舌と口蓋に触れな( ${ }^{3)}$ 大開き母音の「a」 である結果, 中パラ床装着によるロ蓋形態の変化 およびロ肤内容積減少の影響は，他の被検音と比 較し少なく，下額運動の自己㭪正が比較的容易に 行われたものといえる.

また，中パラ床の下頢運動時間および運動量の 経時的变化様相は，全口蓋床の萩原の成績16 之同 様な傾向であったが，中パラ床装着による下顯運 動量の增加量は，全口蓋床のそれと比し小であっ たこのことは中パラ床と全口蓋床の体積の相違 と、形態の相違とがあると推察される.

\section{$\mathrm{V}$. 結諭}

パラタルバーの走行位置の差異が調音器官の 機能に及ぼす影響について梌索する目的で，先ず， その第一段階として，中パラタルバーを有する実 験的局部口蓋床を装着させた結果，被検音の調音 点および調音方法の違いにより, 各器官の機能お よび同器官の自己補正様相が異なることが判明 
した. 今後, 前および後パラタルバーについても 比較検討していく所存です.

\section{文献}

1）山蛒健佑,䅡田正和,園田秀明ほか：発音 機能と補緅処置（その1）, 補綴臨床,9： $147 \sim 159,1976$.

2)虫本和彦,桜井克守,古波蔵鍵一ほか：総 義菌装着者の発音の適応性に関する臨床 的研究,第 1 報語音明瞭度検查,歯科医 学, 40:923 934, 1977.

3）森田啓一：正常者のパラトグラム,ロ病 誌 $34: 279 \sim 309,1967$.

4）園田秀明：発音語明暸度とパラトグラム, 補綴誌, $20: 633 \sim 650,1976$.

5）引田哉：ソナグラフによる発音の砳究。 第 1 報 正常音声の生理学的観察に就い て、柬科学報, $56: 180 \sim 189,1956$.

6）棌井和人，荒井留一,吉沢典男ほか：口蓝 床の発音に及ぼす影響について,菌科学 報, $58: 417 \sim 423,1958$.

7）山腎健佑：発音試験用標準日本語録に関 する研究,補経誌, 8:173〜217, 1964 .

8）大井基道：口蓋裂における模音異常の

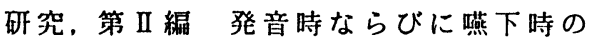
口茼に対する舌圧について,歯科学報，72： 19〜32, 1972.

9）山田昭治：調音時の舌圧変動に関する 実駼的研究, 菊科医学, $47: 68 \sim 87,1984$.

10）江崎梅太郎：口唇の調音機能について, 菌科学報, 60:854 863, 1960 .

11）岩下明弘：語音発声機構に関する管電 図学的研究,耳鼻臨床, 58:712 734, 1965 .

12）虫本和彦：語音発声時の顔面筋活動に 関する研究,第1報両唇の調音機構に ついて,補緅誌, $21: 495 \sim 500,1977$.

13）虫本和彦：語音発声時の顔面觔活動に 関する研究,第 3 報 実験的全口蓋床, 咬合挙上板,咬合举上冠装着後の経日的影 響について,補経誌, $22: 96 \sim 112,1978$.

14）白岩俊男：日本語の語音構成に関する 実験的研究，第 1 編語音構成に関する知 見，日耳宜，48:419〜450, 1942.

15）浜中一将：調音機能と補綴物との関係, I -1. 実験的口蓋床が音声継続時間と。
発音前の表情筋筋放電活動および舌圧之 に及ぼす経日的变化様相,補経誌,34:453 $\sim 466,1990$.

16）萩原正明：調音機能と㭪綴物との関係, II - 1. 実験的口蓋床が発音前の内舌筋能放 電活動, 舌運動および下䪽運動に及ぼす経 日的变化样相,補綴誌, $34: 467 \sim 479,1990$.

17）松本教夫：全部床義菌の発音の研究（そ の 1) 自覚的障害について,口病誌,38: $252 \sim 265,1971$.

18）松本教夫：全部床義菌の発音の研究（そ の2）他覚的障害について,口病誌,38: $333 \sim 362,1971$.

19）別当 敏：全口蓋床に対する発音の適 応に関する㬰験的研究，歯科医学, $37: 557$ $\sim 591,1974$.

20）石嶋誠司：磁気センサを用いた舌運動 計测法ならびに舌の運動特性に関する

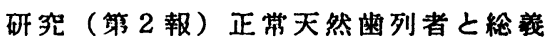
夹装着者の発音時の舌の動態について， 広大雬誌, $17: 128 \sim 137,1985$.

21）菊地亮生.坪田有史,池田㟟子ほか：諸種 㭪綴物の比較統計的観察 VIII,鶴見菌学, 16: $297 \sim 303,1990$.

22）パーシャルデンャーテクニック：藍 稔, 津留宏道,根本一男ほか：第 1 版 第 7 刷, 129 150, 1989.

23）河叧清治：口蓋桿の調音に及ぼす影響に ついて (その1),菌科学報, $59,1: 1 \sim 6,95$ $\sim 99,1959$.

24）友松英美：義菌の発音に及ぼす影響に就 いて，歯科月報，33:295 330, 1959.

25）引田仁哉,荒井賢一,関根弘ほか：義菌設 計に対する音声学的一考察,菌科学報、58 (8), $1 \sim 6,1958$.

26）丸井義仁：上额局部義曾設計に伴う母音 音響相について, 補経誌, $27: 713 \sim 730$, 1983.

27）小塩博司：全口蓋床を基準とした床設計 への適応性に関する音響学的考察，補経 誌, $29: 560 \sim 575,1985$.

28）山本克之,植松秀紀，坪田健呞ほ加：義菌 用チューインガムの付着性に関する研究 第 1 報咀啁時間の相違による影響, 補綴誌, $28: 532 \sim 537,1984$. 
29）川本盛夫：歯科用修復材料の仕上げ研磨 の能率化に関する研究，日大歯学，48:

403〜415, 1974.

30）岡信哲也,神吉ゆかり,高山修ほか：部 分床義歯症例の統計的観察 第 2 報 Co$\mathrm{Cr}$ 金属床義菌について,鶴見菌学, 9:335 $\sim 341,1983$.

31）島 保幸：日本語語音発音時の口蓋に 対する舌圧について,日科誌, $17 ; 376 \sim 387$, 1968.

32）園田頼信：日本語音の発話時における舌 および下䪽の運動特性；J62-A, 555〜 562， 1979.

33）問田直幹、内直耕二、伊藤正男ほか：新 生理学上巻, 1056 1068, 医学書院, 東京, 1982. 